PLPB: Pendidikan Lingkungan dan Pembangunan Berkelanjutan

DOI: https://doi.org/10.21009/PLPB.172.01

DOI: 10.21009/PLPB

\title{
EVALUASI IMPLEMENTASI KEBIJAKAN SISTEM PENYULUHAN PERTANIAN DI KABUPATEN BEKASI
}

\author{
Rasminto \\ Dosen FKIP Geografi Universitas Islam 45 \\ rasminto@gmail.com
}

\begin{abstract}
Bekasi regency as one of the mainstays of agriculture of West Java province is one area that can not escape from the problems of human resource development of agriculture that should get attention by local governments, the private sector and local communities. Many factors that cause deterioration of agriculture in Bekasi Regency, among others; not optimal function of the institution / organization of Agricultural Extension, operational techniques ranging from counseling; extension of distribution, identification of potential areas of extension, aspects of planning and implementation. The purpose of this study was to evaluate the implementation of agricultural extension in Bekasi based aspects of the functions of institutions / organizations and operational technical extension further identify potential areas of agricultural extension.The method used in this study is a qualitative method, ie by observation, interviews and observations documents.The results showed that: (1) Institutions / organizations that form the Executive Agency of Agricultural Extension as an institution is still limited motion in terms of both quantity and quality of personnel, bergaining institutions still sometimes overlaps with the Department of Agriculture. (2) There are still required the addition and improvement of facilities I infrastructure of agricultural extension services so as to improve the quantity and quality of the target areas. (3) Implementation of outreach are still many obstacles execution as their major influence on the political Pilkades, information outreach activities that still have not been absorbed by the farmer that still few farmers who take part in counseling, technology transfer and transfer of regeneration as a target of the main actors, and the synergy between the authorities village extension workers are not optimal.
\end{abstract}

Keywords: Agricultural extension system, Institutions / Organizations, technical operations, and the implementation of agricultural extension.

\begin{tabular}{|l|l|l|l|}
\hline Volume XVII & Nomor 02 & September 2016 & ISSN 1411-1829 \\
\hline
\end{tabular}




\section{Pendahuluan}

Kondisi Indonesia sebagai negara yang didukung dengan potensi sumberdaya alam yang melimpah dan masyarakatnya yang sebagian besar hidup bermatapencaharian sebagai petani dan dengan Indonesia mempunyai pengalaman dengan keberhasilan swasembada pangannya perlu melahirkan bentuk kebijakan dan strategi baru. Dimana sektor pertanian ditempatkan sebagai sektor utama dan penggerak pembangunan dan sektor industri ditempatkan sebagai komplemen pertumbuhan sektor pertanian. Untuk melaksanakannya, diperlukan penjabaran ke dalam kebijakan, dan langkah-langkah operasional berupa terobosan-terobosan baru, sehingga tercapai upaya pembangunan daerah. Pada akhirnya berdampak pada pembangunan nasional.

Dengan kondisi tersebut Jafar (2009) mengatakan bahwa pembangunan pertanian merupakan suatu upaya untuk meningkatkan kualitas, profesionalitas dan produktivitas tenaga kerja pertanian, disertai dengan penataan dan pengembangan kelembagaan pedesaan. Dengan usaha tersebut, maka pendapatan, partisipasi aktif, kesejahteraan petani dan masyarakat pedesaan dapat ditingkatkan, melalui peningkatan produksi komoditas pertanian secara efisien dan dinamis, yaitu diikuti pembagian surplus ekonomi antar berbagai pelaku ekonomi secara lebih adil. Dengan demikian pembangunan daerah dapat dicapai melalui usaha pembangunan pertanian yang pada akhirnya berdampak pada pembangunan nasional.

Dalam pembangunan pertanian tersebut upaya pengembangan sumberdaya manusia sangat berkaitan erat karena petanilah yang mengatur proses dan pelaksanaan dalam usahataninya. Selaras dengan pendapat Jafar yaitu dalam pembangunan pertanian berupaya meningkatkan keberdayaan atau kemampuan di dalam mengelola usaha taninya atau sebagai seorang manajer. Dengan demikian para petani dapat mengambil manfaat dari setiap peluang, agar usahataninya lebih produktif, guna mencapai keuntungan sebesar-besarnya. Pembangunan pertanian harus berbasis pada inovasi dan sumberdaya manusia yang kompeten. Hal tersebut tentunya akan banyak melibatkan kegiatan penyuluhan sebagai suatu

\begin{tabular}{|l|l|l|l|}
\hline Volume XVII & Nomor 02 & September 2016 & ISSN 1411-1829 \\
\hline
\end{tabular}


sistem yang mempunyai peranan strategis dalam pengembangan pengetahuan atau perilaku para pelaku pertanian. Pengetahuan disini termasuk karakter, profesionalisme, etos kerja, disiplin, dan kewirausahaan disamping penataan kembali penyuluhan pertanian sebagai bagian yang tidak terpisahkan dengan adanya perubahan-perubahan di lapangan.

Berdasarkan Undang-Undang Nomor 16 Tahun 2006 tentang Sistem Penyuluhan Pertanian dan Perikanan menyatakan bahwa penyuluhan pertanian adalah proses pembelajaran bagi pelaku utama serta pelaku usaha agar mereka mau dan mampu menolong dan mengorganisasikan dirinya dalam mengakses informasi pasar, teknologi, permodalan, dan sumberdaya lainnya, sebagai upaya untuk meningkatkan produktivitas, efisiensi usaha, pendapatan, dan kesejahteraannya, serta meningkatkan kesadaran dalam pelestarian fungsi lingkungan hidup. Dengan demikian, penyuluhan pertanian sebagai upaya untuk membantu pelaku pertanian dalam menciptakan iklim pembelajaran yang kondusif, dan pada akhirnya mampu mewujudkan masyarakat pertanian yang sejahtera.
Dalam kebijakan sistem penyuluhan pertanian. Pemerintah mengeluarkan seperangkat UndangUndang Nomor 16 Tahun 2006 tentang Sistem Penyuluhan Pertanian dengan tujuan yaitu: 1). Meningkatkan fungsi dan peran Penyuluh Pertanian Swadaya dan Penyuluh Pertanian Swasta dalam penyelenggaraan penyuluhan; 2). Meningkatkan motivasi Penyuluh Pertanian Swadaya dan Penyuluh Pertanian Swasta dalam memfasilitasi petani, Kelompok tani (POKTAN) dan Gabungan Kelompok tani (GAPOKTAN); 3). Menciptakan mekanisme kerja kemitraan antara Penyuluh Pertanian PNS dengan Penyuluh Pertanian Swadaya dan Penyuluh Pertanian Swasta; 4). Meningkatkan kinerja dan profesionalisme Penyuluh Pertanian Swadaya dan Penyuluh Pertanian Swasta.

Sejarah telah membuktikan hasil gemilang atas program dan motivasi yang tinggi para Petugas penyuluh pertanian dalam medukung keberhasilan pembangunan pertanian khususnya keberhasilan dalam pencapaian swasembada beras pada tahun 1984 yang mengantarkan bangsa Indonesia memperoleh

\begin{tabular}{|l|l|l|l|}
\hline Volume XVII & Nomor 02 & September 2016 & ISSN 1411-1829 \\
\hline
\end{tabular}


penghargaan dari Badan Dunia FAO sehingga dapat merubah citra semula sebagai negara pengimpor beras menjadi negara pengekspor beras terbesar di dunia. Namun keberhasilan pencapaian swasembada beras tersebut tidak dapat dipertahankan seiring dengan penurunan kinerja dari para penyuluh pertanian. Dengan kondisi demikian Departemen Pertanian pada periode 2004 - 2009 mencanangkan program pencapaian swasembada dengan lima sasaran komoditas strategis, yaitu padi, jagung, kedelai, daging sapi, dan gula. Salah satu upaya untuk mewujudkan hal tersebut adalah dengan meningkatkan kinerja penyuluh pertanian melalui revitalisasi penyuluhan Pertanian untuk mencapai keberhasilan pembangunan pertanian. Pembinaan terhadap pelaksanaan kegiatan penyuluhan pertanian khususnya bagi Penyuluh Pertanian Swadaya dan Penyuluh Pertanian Swasta selama ini dirasakan belum memiliki arah yang jelas, juga belum didayagunakan secara optimal untuk memenuhi kebutuhan pelaku utama dan pelaku usaha. Dengan demikian perlu adanya Pedoman Pembinaan Penyuluh
Pertanian Swadaya dan Penyuluh Pertanian Swasta.

Menurut Jafar (2009), Penyuluh Pertanian Lapangan dalam melaksanakan fungsi, tugas dan perannya membina petani/ kelompok tani dengan menggunakan sistem kerja Latihan dan Kunjungan (Training-Visit).

Training and Visit (T\&V) diperkenalkan di Indonesia sudah dari tahun 1976 dengan nama Latihan dan Kunjungan (LAKU), sebagai suatu pendekatan penyuluhan yang bertujuan untuk menyediakan pelayanan nasehat kepada petani yang didasarkan kepada jadwal kunjungan yang ketat kepada kelompok tani. Kemampuan, keterampilan maupun sikap petani semakin meningkat, agar para penyuluh pertanian tidak tertinggal maka diperlukan usahausaha peningkatan kemampuan dan kecakapan penyuluh. Salah satu cara dengan menyelenggarakan pelatihanpelatihan bagi penyuluh pertanian secara tertib, teratur dan terarah.

Pendekatan Laku menurut Jafar (2009), menggunakan Trilogi (tiga prinsip dasar) Penyuluhan, yaitu: 1). Terjalinnya hubungan yang akrab antara penyuluh pertanian dengan petani; 2). Materi penyuluhan yang

\begin{tabular}{|l|l|l|l|}
\hline Volume XVII & Nomor 02 & September 2016 & ISSN 1411-1829 \\
\hline
\end{tabular}


diberikan haruslah aktual dan dibutuhkan oleh petani, dan; 3). Penyuluhan pertanian harus menguasai teori maupun praktek materi yang diberikan kepada para petani. Selanjutnya Suhardiyono (1990) dalam Jafar (2009), mengatakan bahwa dalam memudahkan pelaksanaan kegiatan penyuluhan wilayah kerja penyuluh pertanian dibagi habis ke dalam wilayah-wilayah kelompok tani. Pembinaan yang dilakukan oleh seorang penyuluh pertanian lapangan diharapkan dapat meningkatkan peranan petani/ kelompok tani dalam mengantisipasi perkembangan zaman melalui peningkatan teknologi, sehingga dapat meningkatkan produktivitas usaha dan efisiensi serta memanfaatkan peluang pasar guna mencapai tujuan meningkatkan pendapatan dan keejahteraan petani dan keluarganya.

\section{Metodologi Penelitian}

$$
\begin{aligned}
& \text { Metode yang digunakan } \\
& \text { adalah menggunakan metode } \\
& \text { kualitatif. Penggunaan pendekatan } \\
& \text { kualitatif dalam penelitian ini } \\
& \text { dikarenakan: (1) penelitian ini } \\
& \text { menggunakan setting alami sebagai } \\
& \text { sumber data langsung dan peneliti }
\end{aligned}
$$

adalah sumber utamanya,

penelitian juga bersifat deskriptif, dimana data yang dikumpulkan berupa kata-kata, gambar dan bukan angka. Menurut Bogdan dan Biklen, penelitian kualitatif adalah salah satu prosedur penelitian yang menghasilkan data deskriptif berupa ucapan atau tulisan dan perilaku orang-orang yang diamati. (3) menekankan proses kerja dimana fenomena yang dihadapi diterjemahkan ke dalam kehidupan sehari-hari, terutama yang berkaitan langsung dengan masalah sosial, (4) penelitian ini menggunakan pendekatan induktif, abstraksiabstraksi disusun oleh peneliti kebijakan atas dasar data yang telah terkumpul dan dikelompokkan bersama-sama melalui pengumpulan selama kerja di lapangan di lokasi penelitian, (5) peneliti berusaha untuk menemukan dan memahami apa yang tersembunyi di balik fenomena yang kadangkala merupakan sesuatu yang sulit untuk dipahami secara memuaskan. Pendekatan kualitatif diharapkan mampu menghasilkan uraian mendalam tentang suatu setting kontek tertentu yang dikaji dari sudut pandang yang utuh, komprehensif, dan holistik.

\begin{tabular}{|l|l|l|l|}
\hline Volume XVII & Nomor 02 & September 2016 & ISSN 1411-1829 \\
\hline
\end{tabular}


Teknik yang digunakan dalam pengambilan data di antaranya menentukan objek penelitian, mengumpulkan data, mengolah data penelitian, menganalisis hasil penelitian dan menyimpulkan hasil penelitian melalui pengamatan serta keterlibatan langsung, dan menuliskan laporan penelitian.

Pemilihan Kabupaten Bekasi sebagai objek penelitian dilihat dari bahwa Kabupaten Bekasi salah satu daerah yang menjadi andalan lumbung padi Provinsi Jawa Barat seperti daerah Karawang, Indramayu maupun Cianjur. Akan tetapi, semakin hari produktivitas pertaniannya semakin menurun yang disebabkan beberapa faktor penting diantaranya belum optimalnya peran penyuluh pertanian. Oleh karena itu, menjadi suatu hal yang menarik kenapa terjadi hal demikian dalam pelaksanaan penyuluhan pertanian di Kabupaten Bekasi.

Pengumpulan data penelitian ini dilakukan dengan cara melaksanakan: (a) cara pengamatan terlibat, (b) pengamatan terfokus,(c) Pengamatan terseleksi (d) wawancara, dan (e) pembuatan catatan lapangan.
Setelah data penelitian terkumpul data tersebut kemudian diolah dengan menggunakan teknik analisis domain, analisis taksonomi, analisis komponensial dan menemukan tema perilaku.

Dalam penelitian ini pengumpulan data dilakukan melalui observasi, wawancara dan penelusuran dokumen. Adapun prosedur pengumpulan data yang dilakukan melalui; pertama, menyeleksi tempat dan key informan dengan melakukan wawancara untuk mendapatkan informasi secara umum, baik melalui wawancara terbuka maupun wawancara terstruktur. Wawancara terbuka dimaksudkan memberikan gambaran tentang apa yang dikemukakan, dipikirkan, dirasakan, dilakukan dan apa yang diketahui oleh pihak yang diwawancarai. Sedangkan wawancara terstruktur bersifat luwes, pertanyaan dan susunan kata-kata dapat diubah pada saat wawancara yang disesuaikan dengan kebutuhan dan kondisi saat wawancara.

Kedua, melakukan wawancara partisipan yaitu peneliti terlibat dalam kegiatan-kegiatan dan peristiwa yang terjadi pada konteks penelitian, yaitu

\begin{tabular}{|l|l|l|l|}
\hline Volume XVII & Nomor 02 & September 2016 & ISSN 1411-1829 \\
\hline
\end{tabular}


peneliti terlibat langsung dengan kegiatan implementasi penyuluhan pertanian. Proses pengamatan berpartisipasi dilakukan sesuai dengan setting dan sub setting yang ada di lapangan dan terkait langung dengan masalah penelitian. Dalam studi observasi partisipan, peneliti secara nyata terlibat langsung dengan kegiatan orang-orang dalam obyek yang diteliti.

Ketiga, studi dokumentasi dengan melakukan wawancara singkat yakni wawancara sederhana untuk mencari tahu dimana peneliti mendapatkan dokumen yang berhubungan dengan konteks penelitian.

Prosedur Analisis Data

Analisis data berlangsung selama pengumpulan data dilakukan.Secara keseluruhan datadata yang diambil dihimpun dan dimasukan kedalam catatan lapangan (data collection), yang terdiri dari deskripsi data dan refleksi data. Deskripsi data adalah catatan yang dilakukan peneliti sebagaimana adanya data tentang pengamatan , wawancara atau telaah catatan data tulisan (dokumentasi) yang dilakukan peneliti. Sedangkan refleksi data adalah tanggapan peneliti tentang deskripsi data yang ada, sehingga ia merupakan bagian dari analisis data sejak dari awal.

Data yang diperoleh dari catatan lapangan kemudian direduksi (data reduction) melalui proses pemilihan, pemusatan perhatian pada penyederhanaan, pengabestrakan dan transformasi data kasar, menjadi kategori-kategori berdasarkan pengeompokan yang telah ditetapkan peneliti dalam mencari korelasi yang akan disimpulkan. Kategori data-data tersebut disajikan dalam bentuk informasi yang sudah tersusun rapi agar mudah disimpulkan dan diuji keabsahannya. Selanjutanya adalah konklusi data atau verifikasi (conclusion/drawingverification)

yaitu usaha mencari pengertian dari data yang telah dikumpulkan untuk kegunaan analisis selanjutnya.Karena analisi kualitatif pada intinya menggali makna dari data untuk melihat keteraturan, pola-pola, kejelasan proposisi dan lain sebagainya.

Analisis data tersebut dilakukan berulang-ulang dengan memperbandingkan kelompok yang diteliti agar diperoleh teori substantive bisa bersifat deskriptif, yaitu hanya mendeskripsikan data

\begin{tabular}{|l|l|l|l|}
\hline Volume XVII & Nomor 02 & September 2016 & ISSN 1411-1829 \\
\hline
\end{tabular}


temuan apa adanya. Tetapi ia dapat mengembangkan menjadi teori formal Perkembangan teknologi dan atau bersifat proporsional, yaitu jika data temuan tersebut dikembangkan menjadi proposisi-proposisi sehingga menghasilkan kesimpulan yang lebih luas dari sekedar data lapangan.

Temuan yang bersifat deskriptif tersebut kemudian didiskusikan dengan narasumber lain sebagai upaya mencari validasi temuan, kemudian temuan yang bersifat proporsional tersebut selanjutnya dikonprontir dengan kajian teori yang terkait agar memperoleh pendalaman materi yang lebih lanjut. Temuan yang bersifat proposisi ini divalidasi dengan pakar atau yang menghuasai permasalahan tersebut, sehingga diharapkan akan memperoleh masukan untuk dikembangkan pada tahap implementasi penelitian.

\section{Hasil Penelitian Dan Pembahasan}

Penelitian ini bertujuan untuk mengetahui bagaimana implementasi sistem penyuluhan pertanian di Kabupaten Bekasi.

Evaluasi Implementasi Kebijakan Penyuluhan Pertanian di Kabupaten Bekasi

\begin{tabular}{|l|l|l|l|}
\hline Volume XVII & Nomor 02 & September 2016 & ISSN 1411-1829 \\
\hline
\end{tabular}


dengan menerapkan pendekatan yang menetapkan petani sebagai bawahan dan atau alat untuk mencapai tujuan program penyuluhan pertaniannya.

Sampai saat ini metode LAKU (latihan dan kunjungan) yang sudah ada sejak tahun 1976 tetap diterapkan oleh penyuluh pertanian dengan diterapkan kepada berbagai program kebijakan pertanian seperti program MAPAN= mandiri pangan, $\mathrm{SL}$ PTT= sekolah lapang penerapan teknologi pertanian, penerapan benih seperti Impari (imprida padi irigasi) dari varietas 1 sampai lebih dari 60 varietas, IR dengan berbagai varietasnya dan sebagainya.

Melihat kondisi demikian, pemerintah daerah maupun pemerintah pusat untuk segera melakukan pembenahan, penataan, reposisi dan revitalisasi peranan penyuluh pertanian di daerah, dalam rangka membangun kembali sektor pertanian dan kesejahteraan petani dalam menopang perekonomian nasional.

\section{Kebijakan Pengembangan SDM}

\section{Penyuluh Pertanian di Bekasi}

Penyuluh merupakan petugas fungsional yang harus permanen, agar mampu memberikan hasil yang optimal dalam mencerdaskan kehidupan petani dan masyarakat pertanian pada umumnya. Oleh karena itu, mendapatkan pendidikan adalah kebutuhan mutlak bagi setiap penyuluh pertanian. Yang pada kenyataannya tidak semua penyuluh pertanian bisa mendapatkan pendidikan formal untuk meningkatkan kompetensinya. Berdasarkan data di lapangan dalam meningkatkan SDM PPL baru berupa temu tugas THL TBPP.

Kita ketahui penyuluhan pertanian merupakan pendidikan non formal untuk kepentingan masyarakat pertanian, maka wajib mendapatkan prioritas dan perhatian dari Pemerintah Kabupaten Bekasi maupun pemerintah pusat. Sebagaimana amanat UndangUndang Nomor 16 Tahun 2006 tentang sistem penyuluhan pertanian, perikanan, dan kehutanan, dengan mengatur apek-aspek penyuluhan pertanian diantaranya; kelembagaan penyuluhan, ketenagaan penyuluh, pemanfaatan sarana dan prasarana penyuluhan, pembinaan dan pengawasan penyuluh serta pembiayaan penyuluhan.

Undang-Undang penyuluhan sangat diperlukan, untuk

\begin{tabular}{|l|l|l|l|}
\hline Volume XVII & Nomor 02 & September 2016 & ISSN 1411-1829 \\
\hline
\end{tabular}


memposisikan peranan para pelaku utama pertanian dan pelaku usaha serta stakeholder, sehingga mereka dapat memberikan kontribusi, dukungan secara sistematis dan berkesinambungan dalam pengembangan penyuluhan sesuai perkembangan dan tantangannya.

\section{Kebijakan Petani Sebagai Sasaran Pelaku Utama}

Dalam hal ini kebijakan diarahkan kepada upaya petani untuk lebih mendapatkan ilmu pengetahuan, keterampilan dan pengalaman yang ditujukan dalam mensejahterakan keluarga tani dan pengembangan sikap serta perilaku petani. Sehingga mereka dengan mudah dapat menyelesaikan permasalahannya dan dapat mandiri di bidang pertanian dengan mampu merencanakan, melaksanakan dan mengevaluasi segala aspek kehidupan usaha tani secara mandiri.

Respon petani masih sangat tinggi akan keberadaan PPL di wilayahnya dalam memberikan kesadaran dan pemahaman permasalahan pertanian dan penerapan teknologi pertanian, meskipun ada perbuatan oknum ketua poktan dan PPL yang tidak terpuji. Oleh karena itu, perlu sinergisitas antar instansi terkait seperti BP4KKP dan Dinas Pertanian dalam membina petani sebagai pelaku utama terutama peran penyuluh pertanian dan kepala desa dalam membantu mensosialisasikan kegiatan-kegiatan penyuluhan kepada warganya, karena peran aparat desa dalam membangun sinergis dengan Petugas penyuluh di lapangan masih kurang dirasakan, padahal penyuluh secara tidak langsung membantu program desa dalam membina sumberdaya pertanian yang unggul. Selain itu masih ada masalah komunikasi dan pemahaman tugas pokok, fungsi dan kewenangan masing-masingyang harus dipecahkan secara bersamasama agar program penyuluhan dapat berjalan sesuai yang diharapkan bersama.

\section{Kebijakan Kelembagaan Penyuluhan Pertanian}

Berdirinya kelembagaan penyuluhan pertanian secara mandiri merupakan peran pemerintah. Terutama Kabupaten Bekasi sebagai salah satu andalan lumbung penghasil beras utama Jawa barat seperti daerah lainnya seperti Karawang, Indramayu, dan Cianjur yang perekonomian daerahnya berbasis pertanian. Hanya dengan kelembagaan yang kuat,

\begin{tabular}{|l|l|l|l|}
\hline Volume XVII & Nomor 02 & September 2016 & ISSN 1411-1829 \\
\hline
\end{tabular}


memungkinkan berlangsungnya program penyuluhan pertanian secara efektif dan berkelanjutan. Dengan perkembangan dan laju informasi yang pesat, maka tuntutan tersebut terhadap profesionalisme penyuluhan pertanian akan semakin tinggi.

Berdasarkan amanat UndangUndang Nomor 16 Tahun 2006 tentang sistem penyuluhan pertanian, perikanan dan kehutanan pada pasal 8 ayat 2 bahwa kelembagaan penyuluhan yang diamanatkan yaitu: 1) Pada tingkat pusat berbentuk badan yang menangani penyuluhan; 2) Pada tingkat provinsi berbentuk Badan Koordinasi Penyuluhan; 3) Pada tingkat kabupaten/ kota berbentuk badan pelaksana penyuluhan; dan 4) Pada tingkat kecamatan berbentuk Balai Penyuluhan.

Kelembagaan dimaksud, terdiri dari piranti lunak dan piranti keras. Artinya harus ada peraturan yang mengatur secara konkrit legislasi dari penyuluhan pertanian dan ada struktur organisasi yang mengatur tugas dan fungsi serta wewenang dari lembaga penyuluhan. Struktur tersebut untuk memungkinkan manajemen pertanian dapat dikendalikan dan diatur. Sebagai konsekuensi logis, maka yang melekat pada lembaga tersebut adalah sumber daya manusia, sarana prasarana dan materi-materi penyuluhan pertanian yang akan disuluhkan. Lembaga tersebut yang akan menyusun program penyuluhan secara terarah dan sistematis sehingga jelas sasaran dan outputnya.

Secara historis, terbentuknya institusi organisasi Badan Pelaksana penyuluh di tingkat Kabupaten Bekasi mengalami pasang surut. Dengan semangat dari perintis terbentuknya Badan Pelaksana Penyuluhan yang berasal dari penyuluh pertanian yang status pegawainya sebagai jabatan fungsional belum seluruhnya siap Badan ini berdiri. Dari awal dirintisnya pendirian Badan tahun 2007 sempat terjadi beberapa kali pergantian nama Badan. Awalnya berupa BP4KKP (Badan Pelaksana Penyuluhan Pertanian, Perikanan, Kehutanan dan Ketahanan Pangan), dan pada tahun 2008 dirubah menjadi BP4K (Badan Pelaksana Penyuluhan Pertanian, Perikanan dan Kehutanan) dengan dihilangkan bidang ketahanan pangannya, tetapi nama $\mathrm{BP} 4 \mathrm{~K}$ ini tidak bertahan lama dan diganti lagi menjadi BP4KKP di tahun 2009 sampai sekarang. Perubahan tersebut terjadi karena beberapa faktor, diantaranya karena jabatan struktural

\begin{tabular}{|l|l|l|l|}
\hline Volume XVII & Nomor 02 & September 2016 & ISSN 1411-1829 \\
\hline
\end{tabular}


hanya diisi oleh 1 orang pegawai yang berasal dari tenaga penyuluh itupun atas semangat dan dukungan tenaga penyuluh lainnya yang berharap Badan dapat bekerja dalam membina dan memfasilitasi kegiatankegiatan penyuluhan.

Di samping itu, pelaksanaan kordinasi antara institusi penyuluhan yang berupa Balai di tingkat kecamatan dengan pihak kecamatan setempat sering terjadi salah persepsi bahwasanya pihak pegawai kecamatan menganggap PPL itu adalah staf dari Dinas Pertanian, dimana pada tingkat wilayah Dinas Pertanian memiliki UPTD (Unit Pelayanan Teknis Daerah). Sehingga setiap kali Kecamatan mengundang rapat kordinasi untuk PPL baik rapat minggon kecamatan maupun Musrencam (musyawarah perencanaan kecamatan) yang diundang selalu UPTD bukan Balai Penyuluhan.

Selanjutnya dengan kondisi jumlah petugas penyuluh pertanian yang jumlahnya 117 orang PPL yang dibiayai oleh pemerintah dan 1 penyuluh swadaya di Kabupaten Bekasi, jumlah PPL ini sangat dirasakan kurang. Sehingga diperlukan peningkatan secara kuantitas maupun kualitasnya. Idealnya dalam 1 desa terdapat 3 orang PPL yang artinya Kabupaten Bekasi membutuhkan 172 desa x 3 orang PPL $=516$ orang PPL. Karena PPL ini merupakan "arsitek" dalam membuat program pengembangan dan pemberdayaan sumberdaya manusia petani yang unggul.

III Kebijakan Usaha Tani

Kebijakan usaha tani berkaitan erat dengan kebijakan meningkatkan produktivitas dan meningkatkan nilai tambah yang pada akhirnya akan meningkatkan pendapatan usaha tani. Untuk mencapai tujuan ini perlu dibangun sistem usaha tani memcakup subsistem hulu sampai dengan hilir secara terpadu, simultan dan harmonis.

Upaya usaha tani yang dilaksanakan oleh PPL adalah sangat dibutuhkan oleh petani dalam meningkatkan pendapatan ekonomi keluarganya. Oleh karena itu, diperlukan aturan penyediaan, pengaturan dan efisiensi penggunaan air, bibit ternak maupun bibit tanaman, penempatan komoditi yang diusahakan termasuk upah buruh yang sesuai serta paket teknologi yang berdasarkan rekomendasi

\begin{tabular}{|l|l|l|l|}
\hline Volume XVII & Nomor 02 & September 2016 & ISSN 1411-1829 \\
\hline
\end{tabular}


teknologi yang disiapkan oleh pemerintah maupun instansi lain melalui penelitian dan studi-studi pertanian.

Usaha tani tersebut dapat mengantisipasi anomali iklim yang saat ini tidak dapat diprediksi secara pasti sehingga kapan saja dapat mengganggu tanaman. Dengan demikian, dalam kondisi apapun, petani dapat menghasilkan komoditi pertanian dengan produktivitas tinggi dan menguntungkan petani bersama kelompoknya.

\section{Kesimpulan}

Berdasarkan temuan penelitian dan pembahasan hasil penelitian maka dapatlah dirumuskan kesimpulan dan saran penelitian sebagai berikut:

Pertama, Institusi/organisasi yang berbentuk Badan Pelaksana Penyuluhan Pertanian masih terbatas geraknya secara institusi baik dari segi kuantitas maupun kualitas personil, bergaining institusi terkadang masih tumpang tindih dengan Dinas Pertanian. Oleh karena itu, pemerintah daerah perlu mereposisi dan merevitalisasi Badan Pelaksana Penyuluhan Pertanian,
Perikanan, Kehutanan dan Ketahanan Pangan.

Kedua, Diperlukan penambahan dan perbaikan sarana/prasarana penyuluhan pertanian sehingga dapat meningkatkan kuantitas dan kualitas daerah binaan.

Ketiga, Impelementasi penyuluhan yang masih banyak kendala pelaksanaan seperti adanya pengaruh besar dari politik pilkades, informasi kegiatan penyuluhan yang masih belum terserap oleh petani sehingga masih sedikit petani yang mengikuti kegiatan penyuluhan, alih teknologi dan alih regenerasi sebagai sasaran pelaku utama, dan sinergisitas antara aparat desa dan petugas penyuluh yang belum optimal.

Keempat, Pemerintah Daerah dan Pemerintah Pusat segera memberikan kesempatan bagi penyuluh pertanian untuk meningkatkan kompetensinya serta menambah kuantitas penyuluh pertanian agar kinerja institusi dan penyuluhan dapat lebih meningkat dalam menjangkau pembinaan wilayah penyuluhan.

\section{Daftar Pustaka}

Abdul Wahab, Solichin. 2005. Analisis Kebijaksanaan dari

\begin{tabular}{|l|l|l|l|}
\hline Volume XVII & Nomor 02 & September 2016 & ISSN 1411-1829 \\
\hline
\end{tabular}


Formulasi ke Implementasi Kebijaksanaan Negara. Jakarta: PT Bumi Aksara

Hafsah, Mohammad Jafar. 2009. Penyuluhan Pertanian di Era Otonomi Daerah.

Jakarta:Pustaka Sinar Harapan

Keraf, A. Sonny. 2005. Etika Lingkungan. Jakarta: Kompas

Nurmala, Tati. et.al. 2012. Pengantar Ilmu Pertanian. Yogyakarta: Graha Ilmu

Purnaweni, Hartuti. 1991. Kebijakan Publik . Semarang: FISIPUndip

Saftana dan Haris. 2007. Pembangunan Pertanian Berkelanjutan Melalui Kemitraan Usaha.

Jakarta: Jurnal Litbang Pertanian

Soemarwoto, Otto. 2001. Atur-DiriSendiri: Paradigma Baru Pengelolaan Lingkungan Hidup. Pembangunan ramah lingkungan, berpihak pada rakyat, ekonomis, berkelanjutan. Yugyakarta: Gadjah Mada University Press

Sukardi, HM. 2008. Evaluasi Pendidikan Prinsip dan Operasionalnya. Jakarta: PT. Bumi Aksara

Undang-Undang RI Nomor 16 Tahun 2006 tentang Sistem Penyuluhan Pertanian, perikanan dan kehutanan. 